\title{
Pendistribusian Dana Zakat Infak Sedekah (ZIS) Untuk Pemberdayaan Masyarakat Studi Kasus BMT Amanah Ummah Sukoharjo
}

\author{
Sumarni \\ Fakultas Syariah, Institut Agama Islam Darussalam (IAID) Ciamis Jawa Barat, Indonesia \\ Email korenpondensi: nunusumarni00@gmail.com
}

Recieved 28-06-2018 | Revised 05-07-2018 | Accepted 24-07-2018

\begin{abstract}
This study aims to determine: 1) The position of Baitul Mal at BMT Amanah Ummah 2) Model of financing BMT Amanah Ummah for the dhuafa (poor people). 3) Distribution of ZIS funds for community empowerment in BMT Amanah Ummah. This method of research used descriptive qualitative approach. This research was conducted in BMT Amanah Ummah Sukoharjo in June until August 2016. The subject of the study was Amil treasury of BMT Amanah Ummah. Informants were Baitul Mal employees and mustahiq. Method of collecting data was done by observation, interview and documentation. The results of this study, namely, 1) the separation of management between Baitul Mal and Baitul Tamwil. The Baitul Mal of BMT Amanah Ummah has its own manager and management. 2) Model of financing for the dhuafa at the Baitul Mal of BMT Amanah Ummah is to use qardhul hasan financing agreement, in the form of revolving fund used to finance or develop dhuafa's bussiness. 3) The distribution of funds of Zakat Infaq and alms (ZIS) at Baitul Mal BMT Amanah Ummah is allocated to programs of empowerment, health, education and charity. A larger portion of fund is allocated to the development programs.
\end{abstract}

Keywords: Distribution, Zakat, Infaq, alms, BMT Amanah Ummah, The empowerment of community

Saran sitasi: Sumarni, S. (2018). Pendistribusian Dana Zakat Infak Sedekah (ZIS) untuk Pemberdayaan Masyarakat Studi Kasus BMT Amanah Ummah Sukoharjo. Jurnal Ilmiah Ekonomi Islam, 4(02), 116-125. doi:http://dx.doi.org/10.29040/jiei.v4i2.261

DOI: http://dx.doi.org/10.29040/jiei.v4i2.261

\section{Pendahuluan}

Masalah kesejahteraan dan ekonomi selalu menjadi hal utama dalam pembangunan suatu Negara. Salah satunya Indonesia, sejak Indonesia merdeka problematika pemberdayaan umat untuk mencapai kesejahteraan selalu menarik untuk dibahas. Masalah kemiskinan dan pengangguran selalu muncul dalam wacana teori ekonomi. Pembangunan yang dilakukan masih saja menimbulkan permasalahan, utamanya mengenai pengangguran, kepincangan distribusi pendapatan, dan kesenjangan kesejahteraan.

Sedangkan Islam memberikan keyakinan, dan jalan hidup untuk umat manusia agar dapat mengatasi segala permasalahan yang dihadapi dan membimbing menuju kehidupan bahagia di dunia dan akhirat. Islampun melihat kehidupan individu sama pentingnya dengan pembangunan kehidupan sosial. Dimana hal ini berarti Islam juga mengajarkan tentang keadilan dan persaudaraan dalam masyarakat. Dalam tatanan hubungan sosial kaum miskin dan kaum kaya harus menciptakan hubungan harmonis. Hubungan kaya-miskin dalam syari'at Islam dilandaskan pada aksioma, di dalam harta orang kaya terdapat hak orang miskin yang meminta dan orang miskin yang tidak meminta, sebagaimana firman Allah: 


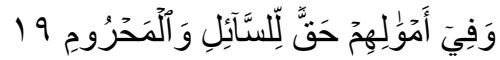

"Dan pada harta-harta mereka ada hak untuk orang miskin yang meminta dan orang miskin yang tidak mendapat bagian" (AdDzariyat: 19).

Islam menganjurkan untuk membagikan harta lewat zakat, infak dan sedekah guna menjaga keharmonisan dalam kehidupan sosial (Sudarsono, 2003). Umat Islam diharuskan bekerja dan berusaha untuk membantu saudara muslim yang masih miskin supaya hidup lebih layak dan berdaya. Kerja kolektif ini, dilakukan dalam kerangka tanggungjawab sosial. Setiap orang secara bersama-sama memiliki tanggungjawab mulia, untuk mengentaskan kemiskinan umat. Kerjasama ini dilakukan melalui mekanisme Zakat Infak Sedekah (ZIS).

Zakat menurut istilah agama Islam artinya kadar harta yang tertentu, yang diberikan kepada yang berhak menerimanya dengan beberapa syarat (Rasjid, 2005). Infak berarti mendermakan atau memberikan rizki (karunia Allah) atau menafkahkan sesuatu kepada orang lain berdasarkan rasa ikhlas dan karena Allah semata (Padlullah, 1993). Sedangkan Sedekah pada prinsipnya sama dengan infaq tetapi memiliki pengertian yang lebih luas berupa pengucapan kalimat thayyibah juga termasuk memberikan bantuan tenaga atau jasa serta menahan diri untuk tidak berbuat kejahatan (Ilmi, 2002). Zakat Infaq dan Sedekah (ZIS) menjadi pemecah masalah kemiskinan dan kepincangan sosial.

Pendistribusian zakat yang selama ini sudah berlaku di masyarakat muslim pada umumnya lebih bersifat konsumtif. Pada malam Idul Fitri misalnya, panitia zakat masjid atau mushola dengan anggota kelompoknya membagi-bagikan beras atau uang ke rumah-rumah orang yang tidak mampu, dan memberikannya kepada abang-abang becak di jalan-jalan secara instan. Memang sepintas lalu, apa yang dilakukan oleh panitia zakat ini mampu sedikit membantu beban ekonomi para dhuafa tersebut dalam waktu beberapa hari. Karena anggaran makan 3 kali selama 1-2 hari telah tercukupi dengan pem- berian panitia zakat. Namun, kemudian muncul pertanyaan, apakah model pendistribusian seperti ini mampu mengubah nasib ekonomi mereka. Tentu masih jauh dari harapan yang kita idamidamkan selama ini, yakni bagaimana mengubah nasib ekonomi para mustahiq (orang yang berhak menerima zakat), yang asalnya hanya sekedar penerima zakat, menjadi muzakki (orang yang mengeluarkan zakat), dan bagaimana bisa merubah status sosial ekonomi para muzakki.

Pertumbuhan dana zakat yang dikumpulkan BAZNAS pada Januari-April 2015, yakni bertumbuh $37 \%$ dibanding periode yang sama pada 2014 (bisnis.com, 2015). Angka ini mengalami kenaikan yang cukup signifikan pada sebuah lembaga pengumpul zakat. Selain BAZNAS, LAZ, LAZIS dan lain sebagainya, lembaga pengelola ZIS juga bisa melalui Baitul Mal wat Tamwil (BMT). Karena lembaga BMT merupakan sebuah lembaga keuangan yang memiliki dua unit usaha sekaligus dalam bidang pengelolaan ZIS dan perbankan syariah (Maal dan Tamwil). Peran BMT sangat dinanti oleh masyarakat terutama konomi kelas bawah terutama pada sisi Baitul Malnya.

Dengan demikian perlu ditegaskan bahwa untuk bisa disebut BMT, sebuah lembaga keuangan de facto harus memiliki dua unit usaha sekaligus dalam bidang pengelolaan ZIS dan perbankan syariah (Ilmi, 2002). Bila salah satunya tidak ada, maka bukanlah yang demikian disebut sebagai BMT tetapi Baitul Mal (BM) saja atau Baitul Tamwil (BT) saja. Keduanya merupakan suatu system dalam wadah BMT yang bekerja sinergi dan tidak dapat dipisahkan satu sama lain. Bila hanya salah satu maka telah terjadi pengingkaran pada prinsip jati diri BMT sebagai lembaga mikro keuangan syariah.

Menurut Asytuti (2012), BMT adalah salah satu wujud dan implementasi nilai syariah dalam bentuk lembaga keuangan kecil atau micro. Kebutuhan microfinance yang kuat merupakan amanah undang-undang dan sekaligus perwujudan dari ekonomi kerakyatan yang dibangun sebagai dasar ekonomi bangsa. 
Berpijak dari berbagai peran dan keberhasilan BMT dalam pemberdayaan perekonomian umat bahwa secara ekonomi dan keuangan, BMT layak diperhitungkan dan signifikan dalam meningkatkan ekonomi rakyat (Yusuf, 2014). Alternatif (pilihan) menjadikan BMT sebagai sebuah lembaga keuangan terpercaya, dalam arus perekonomian modern, makin terbuka bagi umat Islam. BMT telah mampu berperan aktif dalam membantu memberdayakan perekonomian para pelaku ekonomi lemah. Peran strategis yang ditunjukan BMT sebagai alternatif wadah simpan pinjam dan bermitra kerja, telah mampu menumbuhkan respon positif baik secara moril maupun material.

Salah satu BMT yang ikut dalam kegiatan pengelolaan dan pendistribusian ZIS adalah BMT Amanah Ummah Sukoharjo. Saat ini dana ZIS pada BMT Amanah Umah didistribusikan tidak hanya untuk kegiatan konsumtif saja, tetapi juga produktif, salah satunya dengan program MINA BARU. Program ini bertujuan untuk meningkatkan taraf hidup mustahiq menjadi muzakki. Harapan manajemen Baitul Mal BMT Amanah Ummah Sukoharjo terhadap program ini adalah adanya ketentraman kehidupan mustahiq dapat terjamin dan tidak selamanya tergantung dengan pemberian bahkan dalam jangka panjang diharapkan dapat berubah menjadi $\mathrm{mu}$ zakki.

Program pendistribusian ZIS untuk pemberdayaan masyarakat yang ada pada BMT Amanah Ummah tersebut menarik untuk diteliti lebih jauh. Untuk mengetahui sejauh mana BMT Amanah Umah memanfaatkan dana Baitul Mal (zakat, infak, sedekah) yang telah diberikan muzakki untuk didistribusikan secara tepat guna dan produktif kepada mustahiq dalam pemberdayaan masyarakat, perlu diadakan penelitian lebih lanjut mengenai "Pendistribusian Dana Zakat Infak Sedekah (ZIS) Untuk Pemberdayaan Masyarakat Studi Kasus BMT Amanah Ummah Sukoharjo".

Berdasarkan latar belakang yang dikemukakan diatas, bahwa permasalahan yang muncul dalam penelitian ini adalah bagaimana: 1). Kedu- dukan fungsi Baitul Mal BMT Amanah Ummah Sukoharjo, 2). Model pembiayaan Baitul Mal BMT Amanah Ummah untuk mustahiq, 3). Implementasi pendistribusian Zakat Infak Sedekah (ZIS) pada BMT Amanah Ummah Sukoharjo.

Tujuan dilakukannya penelitian ini adalah untuk mengetahui: 1). Kedudukan Baitul Mal pada BMT Amanah Ummah Sukoharjo, 2). Model pembiayaan yang diberikan Baitul Mal BMT Amanah Ummah kepada mustahiq, 3). Implementasi pendistribusian Zakat Infak Sedekah (ZIS) pada BMT Amanah Ummah Sukoharjo.

\section{Tinjauan Teori}

\subsection{Pengertian Baitul Mal}

Baitul Mal berasal dari bahasa Arab (bayt al-mal) yang bermaksud "rumah harta" (Ridwan, 2013). Menurut Dahlan, et al. (2003), Baitul Mal merupakan lembaga Negara yang bertugas menerima, menyimpan dan mendistribusikan uang Negara sesuai syariat Islam.

Menurut Zallum (2009), Baitul Mal merupakan institusi khusus yang menangani harta yang diterima Negara dan mengalokasikanya bagi kaum muslim yang berhak menerimanya. Baitul Mal dapat juga diartikan secara fisik sebagai tempat (al makan) untuk menyimpan dan mengelola segala macam harta yang menjadi pendapatan negara. Jadi, Baitul Mal merupakan lembaga atau pihak (Arab: al jihat) yang mempunyai tugas khusus menangani segala harta umat, baik berupa pendapatan maupun pengeluaran Negara (Zallum, 2009).

Pengertian Baitul Mal menurut para Ulama ialah Pihak yang mengelola keuangan Negara, mulai dari menghimpun, memungut, mengembangkan, memelihara hingga menyalurkannya. Definisi tersebut ditegaskan oleh Al-Mawardi (t.t) dalam kitab Ahkam Sulthoniyyah dengan mendefinisikannya sebagai tempat/wadah untuk memelihara/ menjaga hak-hak keuangan Negara. Baitul Mal juga diartikan petugas yang berwenang dalam mengatur keuangan Negara tersebut.

Baitul Mal pertama sekali dirumuskan dan didirikan oleh Rasulullah SAW dengan sangat 
simple. Selanjutnya dimasa kekhalifahan Abu Bakar tidak terlalu ada perubahan yang besar berkaitan dengan Baitul Mal. Perubahan yang besar terjadi pada masa kekhalifahan Umar Bin Khattab karena sumber pendapatan Negara melimpah, untuk menyelamatkan kas Negara dan mempertahankan stabilitas ekonomi dan keuangan maka didirikanlah Baitul Mal (Rivai dan Usman, 2012).

\subsection{Baitul Mal wat Tamwil (BMT)}

BMT singkatan dari Baitul Mal wat Tamwil, bila diterjemahkan dalam bahasa Indonesia Secara singkat, berasal dari bahasa arab, bait almal merupakan lembaga pengumpulan dana masyarakat yang disalurkan tanpa tujuan profit. Sedangkan bait at-tamwil merupakan lembaga pengumpulan dana (uang) guna disalurkan dengan orientasi profit dan komersial (Sumiyanto, 2008).

BMT merupakan salah satu jenis lembaga keuangan bukan bank yang bergerak dalam skala mikro sebagaimana Koperasi Simpan Pinjam (KSP). BMT berbeda dengan Bank Umum Syari'ah (BUS) maupun Bank Perkreditan Syari'ah (BPRS).

\subsection{Tinjaun tentang Zakat Infak dan Sedekah Zakat}

Zakat menurut istilah agama Islam artinya kadar harta yang tertentu, yang diberikan kepada yang berhak menerimanya dengan beberapa syarat (Rasjid, 2005). Menurut Mubasirun, zakat merupakan institusi resmi yang diarahkan untuk menciptakan pemerataan dan pemberdayaan masyarakat sehingga taraf kehidupan masyarakat dapat ditingkatkan (Mubasirun, 2013)

Konsep Zakat ini adalah salah satu ibadah di bidang harta yang memiliki nilai-nilai sosial, sehingga dalam pelaksanaannya memerlukan tata cara perhitungan dan pembagiannya juga diperlukan sekelompok orang yang bertugas mengelola segala aspek perzakatan, tidak diserahkan pada kesadaran individu masing-masing.

Zakat menurut Undang-undang No 23 tahun 2011 tentang pengelolaan zakat dijelaskan bahwa zakat adalah harta yang wajib dikeluarkan oleh seorang muslim atau bandan usaha untuk diberikan kepada yang berhak menerimanya sesuai dengan syariah Islam.

Hukum zakat yang wajib meniscayakan bahwa zakat merupakan bentuk kedermawanan dan juga bentuk ketaatan kepada Allah SWT. Sehingga harus diperhatikan mengenai tata cara pembayaran dan pembagiannya, zakat sebagai ibadah yang jika tidak dilaksanakan, ada hak orang laian yang terambil (Ridwan, 2013).

\section{Infak}

Infaq berasal dari kata nafaqa, yang berarti tela lewat, berlalu, habis, mengeluarkan isi, menghabiskan miliknya, atau belanja (Ridwan, 2013). Infaq adalah mengeluarkan harta tertentu untuk dipergunakan bagi suatu kepentingan yang diperintahkan oleh Allah SWT (Ridwan, 2013). Dalam Undang-undang Nomor 23 tahun 2011 disebutkan bahwa infak adalah harta yang dikeluarkan oleh seseorang atau badan usaha di luar zakat untuk kemaslahatan umum. Infak berarti mendermakan atau memberikan rizki (karunia Allah) atau menafkahkan sesuatu kepada orang lain berdasarkan rasa ikhlas dan karena Allah semata (Padlullah, 1993).

\section{Sedekah}

Sedekah berasal dari kata ash-shidqu, yang berarti orang yang banyak benarnya dalam perkataan, bahkan diungkapkan bagi orang yang sama sekali berdusta. Sedekah menurut syara' adalah melakukan suatu kebajikan sesuai dengan ajaran al-Qur'an dan as-Sunnah, baik yang bersifat materiil maupun non materiil. Sedangkan menurut Undang-undang nomor 23 tahun 2011 menyebutkan bahwa sedekah adalah harta atau nonharta yang dikeluarkan oleh seseorang atau badan usaha di luar zakat untuk kemaslahatan umum.

Secara umum, kebaikan seseorang dalam bentuk memberikan sebagian harta yang dimilikinya kepada orang/pihak lain disebut Sedekah. Sedekah yang wajib disebut zakat yang sudah ditentukan kadar (persentase zakat), nisab (batas minimal harta yang dizakati), dan haul (ukuran waktu satu tahun)-nya, dan infak (berlaku untuk jenis harta baru yang tidak terdapat pada zaman Nabi SAW, sehingga tidak ditentukan kadar, 
nisab dan haulnya). Adapun Sedekah yang sunnat disebut Sedekah tathowwu' (Ridwan, 2013)

Sedekah pada prinsipnya sama dengan infaq, hanya saja ia memiliki pengertian yang lebih luas. Sedekah dapat berupa bacaan tahmid, takbir, tahlil, istighfar, maupun bacaan-bacaan kalimah thayyibah lainnya. Demikian juga Sedekah dapat berupa pemberian benda atau uang, bantuan tenaga atau jasa serta menahan diri untuk tidak berbuat kejahatan. Adapun infaq tidaklah demikian. Hal lain yang membedakan keduanya adalah bahwa infaq dikeluarkan pada saat seseorang menerima rizki, sedangkan Sedekah lebih luas dan lebih umum lagi. Tidak ditentukan jenisnya, jumlahnya, waktu penyerahannya serta peruntukannya (Padlullah, 1993).

Sedekah adalah keseluruhan amal kebajikan yang dilakukan setiap pribadi muslim untuk menciptakan kesejahteraan sesama umat manusia, termasuk untuk kelesctarian lingkungan hidup dan alam semesta ciptaan Ilahi guna memperoleh hidayah dan ridho Allah.

\subsection{Qordhul Hasan}

Al-Qordh adalah pemberian harta kepada orang lain yang dapat ditagih atau diminta kembali atau dengan kata lain meminjamkan tanpa mengharapkan imbalan (Antonio, 2001). Dalam literature fiqih klasik, qardh, dikategorikan dalam aqd tathawwuni atau akad saling membantu dan bukan transaksi komersil (Sabiq, 1987). Aplikasi dalam perbankan dan BMT, akad qordh untuk menyumbang usaha kecil atau membantu sektor sosial yaitu dikenal dengan produk al-qordh al-hasan.

Manfaat akad al-qordh diantaranya:

a. Memungkinkan nasabah yang sedang dalam kesulitan mendesak untuk mendapatkan talangan jangka pendek

b. Al-qordh al-hasan juga merupakan salah satu ciri pembeda antara lembaga keuangan syariah dan konvensional yang di dalamnya terkandung misi sosial, disamping misi komersial.

c. Adanya misi sosial kemasyarakatan ini akan meningkatkan citra baik dan meningkatkan loyalitas masyarakat terhadap lembaga

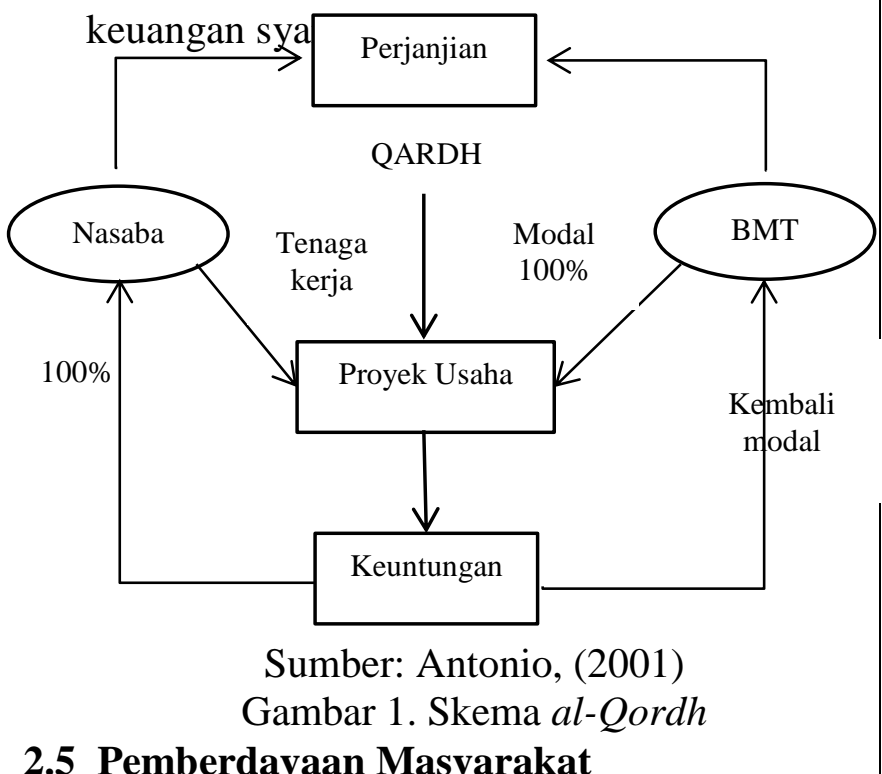

\subsection{Pemberdayaan Masyarakat}

Pemberdayaan menurut Rofiah (2011) dilahirkan dari bahasa inggris, yakni empowerment yang mempunyai makna dasar 'pemberdayaan' dimana daya bermakna kekuatan (power). Pemberdayaan adalah upaya untuk membangun daya itu dengan mendorong memotivasi dan membangkitkan kesadaran atau potensi yang dimilikinya serta berupaya untuk mengembangkannya. Upaya itu harus diikuti dengan memperkuat potensi dan daya yang dimiliki oleh masyarakat (Mufraini, 2006).

Proses pemberdayaan masyarakat menurut Rohmat (2015) ditentukan oleh dua faktor yaitu:

a. Eksogen, merupakan faktor-faktor yang berasal dari luar masyarakat baik berkenaan kebijakan pemerintah, bantuan biaya bantuan tenaga penyuluh dan sebagainnya.

b. Endogen, merupakan faktor dari dalam yang berkaitan dengan tata nilai, adat kebiasaan, sikap mental dari masyarakat itu sendiri.

Menurut Quzwini (2013), Pemberdayaan memiliki dua kecenderungan yaitu kecenderungan primer dan kecenderungan sekunder. Kecenderungan primer merupakan pemberdayaan yang menekankan pada proses memberikan atau mengalihkan sebagian kekuasaan, kekuatan atau kemampuan kepada masyarakat agar individu menjadi lebih berdaya, kecenderungan sekunder, merupakan pemberdayaan yang menekankan pada proses menstimulasi, mendorong 
atau memotivasi individu agar mempunyai kemampuan atau keberdayaan untuk menentukan apa yang menjadi pilihan mereka.

Agen pembangunan budaya pemberdayaan masyarakat harus mampu menciptakan, mempromosikan, dan meningkatkan kesempatan untuk berpartisipasi, pengembangan pemberdayaan masyarakat (Sonn and Quayle, 2014). Dalam terminologi manajemen, pemberdayaan berkaitan dengan wewenang (authority) dan kekuasaan (power). Menurut Quswini, Pemberdayaan bertujuan menghapuskan hambatan-hambatan guna membebaskan organisasi dan orang-orang yang bekerja di dalamnya, melepaskan mereka dari halangan-halangan yang hanya memperlamban reaksi dan merintangi aksi mereka.

\section{Metode Penelitian}

Penelitian ini menggunakan pendekatan penelitian kualitatif dan penelitian yang dilakukan termasuk tipe penelitian dekriptif. Dalam penelitian ini peneliti mendiskripsikan data dengan kata-kata, kalimat dan mengurai bukan dengan angka. Dalam penelitian kualitatif, instrument atau alat penelitian adalah peneliti itu sendiri melalui evaluasi diri seberapa jauh pemahaman terhadap metode kualitatif, penguasaan teori dan wawasan terhadap bidang yang diteliti, serta kesiapan dan bekal memasuki lapangan. Penelitian kualitatif sebagai human instrument berfungsi menetapkan fokus penelitian, memilih informan sebagai sumber data, dan membuat kesimpulan atas temuannya (Abdullah dan Saebani, 2014).

Tipe penelitian deskriptif bertujuan untuk mendeskripsikan apa yang saat ini berlaku. Di dalamnya terdapat upaya mendeskripsikan, mencatat, analisis dan menginterpretasikan kondisikondisi yang sekarang ini terjadi atau ada. Menurut Mardalis (1990) penelitian deskriptif bertujuan untuk memperoleh informasi-informasi mengenai keadaan saat ini, dan melihat kaitan antara variabel-variabel yang ada. Penelitian ini tidak menguji hipotesa atau tidak menggunakan hipotesa, melainkan hanya mendeskripsikan informasi apa adanya sesuai dengan variablevariabel yang diteliti.

Ciri lain metode deskriptif adalah titik berat pada observasi dan suasana alamiah (naturalistis setting). Peneliti bertindak sebagai pengamat. Ia hanya membuat kategori perilaku, mengamati gejala dan mencatatnya dalam buku observasi (Rakhmat, 2005). Peneliti terjun ke lapangan tanpa di bebani atau diarahkan oleh teori. Penelitian ini merupakan bagian dari penelitian Islamic studies dengan pendekatan ortopraksi yaitu melihat Islam sebagai gejala sosial (Bakri, 2014).

Penelitian ini di lakukan di BMT Amanah Ummah Sukoharjo. Waktu penelitian adalah bulan Juni sampai Agustus 2016. Subyek penelitiannya adalah Amil Baitul Mal yang mendistribusikan dana zakat, infak dan sedekah untuk pemberdayaan masyarakat. Informan penelitian ini adalah karyawan dan mustahiq. Metode pengumpulan data menggunakan observasi, wawancara dan dokumentasi. Pemeriksaan keabsahan data menggunakan triangulasi sumber.

\section{Hasil dan Pembahasan}

\section{Kedudukan Baitul Mal BMT Amanah Ummah}

Kedudukan Baitul Mal BMT Amanah Ummah memiliki pengelola dan pengelolaan tersendiri. Dengan pengelolaan yang terpisah ini, permasalahan yang dihadapi dhuafa dengan fungsi bisnis (tamwil) yang ada pada BMT Amanah Ummah telah di jembatani dengan penguatan lembaga BMT melalui fungsi sosial (mal) BMT. Dengan penguatan mal tersebut masyarakat miskin dapat terlayani dengan produk Qordhul hasan (dana-dana kebajikan) yang berasal dari dana ZIS BMT Amanah Ummah. Hal tersebut dilaksanakan atas dasar semangat pemberdayaan masyarakat dhuafa, peningkatan taraf hidup mereka serta kemandirian secara ekonomi. Sehingga pada akhirnya harapan meningkatkan taraf hidup mustahik menjadi muzzaki menjadi terwujud.

Walaupun dalam pengamatan penyusun di lapangan manager Baitul Mal melakukan kegiatan secara dominan dalam setiap program. Namun dengan memiliki manajemen pengelolaan yang terspisah antara Mal dan Tamwil dapat 
disimpulkan bahwa BMT Amanah Ummah lebih baik.

Konteks Baitul Mal yang ada pada zaman Rosulullah SAW dan sahabat memang berbeda dengan yang ada pada Baitul Mal di BMT Amanah Ummah Sukoharjo. Waktu itu Baitul Mal memiliki peran yang sangat luas yaitu mengatur ekononi suatu Negara. Namun konsep Baitul Mal yang ada pada zaman Rasulullah, Khulafaur Rassidin, Umayah dan Abbasiah dapat di aplikasikan pada Baitul Mal BMT Amanah Ummah Sukoharjo yaitu pengumpulan dan pendistribuasian dana ZIS dengan menyeimbangkan fungsinya dengan Tamwil. sehingga orientasi sebuah lembaga keuangan syariah utamanya BMT tidak hanya profit oriented tetapi seimbangn antara keduanya.

Hal ini sekaligus merupakan sebuah penegasan istilah yang secara de fakto, BMT sendiri adalah singkatan dari Bitul Mal wat Tamwil (Mal dan Tamwil). Jikalau dalam sebuah intitusi BMT hanya terdapat salah satu bidang saja maka bukan demikian disebut BMT. Tetapi Baitul Mal saja atau baitul tamwil saja (Ilmi, 2002). Pengertian BMT menegaskan bahwa BMT terdiri dari bait al mal yaitu melakukan kegiatan non profit dan bait at tamwil yaitu melakukan kegiatan yang berorientasi komersial atau profit oriented (Sumiyanto, 2008). BMT Amanah Ummah Sukoharjo telah mengimplementasikan kedua unsur tersebut.

\section{Model Pembiayaan Usaha Mustahiq}

Model pembiayaan untuk mustahiq yang di lakukan Baitul Mal BMT Amanah Ummah adalah untuk membiayai usaha yang bersifat produktif untuk pemberdayaan. Pembiayaan ini dilakukan dalam bentuk pinjaman dana Qardhul hasan. Dana tersebut sifatnya bergulir, digunakan untuk membiayai atau mengembangkan usaha kaum dhuafa. Pemberdayaan masyarakat melalui sektor riil merupakan langkah yang strategis dalam mengembangkan ekonomi kelas bawah yang sangat membutuhkan bantuan pinjaman modal untuk mengembangkan usahanya melalui pemberian pinjaman kebajikan (qardhul hasan).
Dalam pengelolaannya, Baitul Mal BMT Amanah Ummah mengelola sendiri secara langsung. Untuk mnghindari penyalahgunaan dana qardhul hasan, pengelola Baitul Mal terlebih dahulu akan melakukan survey secara ketat terhadap kondisi ekonomi dan usaha yang akan di jalankan oleh dhuafa tersebut. Setelah melakukan pencairan dana maka akan dilakukan pendampingan usaha secara periodik minimal satu bulan sekali.

Qardhul hasan yang diberikan BMT hanya untuk penyediaan alat-alat usaha. Sedangkan untuk bahan baku penjualan BMT memberikan pembiayaan murabahah. Hal ini dilakukan karena banyaknya dhuafa binaan, sementara ketersediaan dana terbatas. Itu artinya Baitul Mal menerapkan dua akad pembiayaan pada pembiayaan dhuafa. Hal ini tentu akan rancu karena qardhul hasan adalah akad pembiayaan yang bersifat not profit berdasarkan akad tabarru' (tolong menolong). Sedangkan murabahah adalah akad jual beli yang bersifat komersial.

Hal ini berdasarkan hadits yang diriwayatkan oleh ahmad an-nasai dar Abu Hurairah RA:

$$
\text { ان النبي صلي الله عليهو سلم نهي عن بيعتين في بيعة }
$$

"Bahwa Nabi Shallallahu 'alaihi wasallam melarang melakukan dua transaksi dalam satu transaksi jual beli" (Hadits At-Tirmidzi dan Ibnu Hibban)"

\section{Implementasi pendistribusian ZIS untuk pemberdayaan masyarakat pada BMT Amanah Ummah Sukoharjo}

Implementasi pendistribusian ZIS oleh BMT Amanah Ummah yang diteliti ini mencakup kegiatan jangka panjang dan jangka pendek. Program-program yang ada pada Baitul Mal BMT Amanah Ummah Sukoharjo meliputi program pemberdayaan, pendidikan, kesehatan dan charity. Untuk kegiatan jangka panjang pendayagunaan ZIS dialokasikan untuk program pemberdayaan yang sudah ada. Dalam skala lebih luas, dana tersebut disalurkan juga pada programprogram pendidikan, kesehatan dan charity. 
Sumber utama yang digunakan dalam program pemberdayaan pada BMT Amanah Ummah adalah berasal dari infak dan sedekah. Ini dilakukan karena sumber dana infak dan sedekah lebih besar dibandingkan zakat. Infak dan sedekah juga mempermunah BMT Amanah Ummah Sukoharjo untuk menjadikannya dana bergulir karena tidak ada jangka waktu untuk pentasyarufannya. Berbeda dengan zakat yang memiliki jangka waktu pentasyaraufan. BMT Amanah Ummah membina kemudian menciptakan usaha baru untuk dhuafa. Ada juga beberapa usaha yang sudah ada kemudian usaha tersebut dibiayai oleh BMT. Dhuafa datang sendiri dan mengajukan pembiayaan kepada BMT Amanah Ummah Sukoharjo.

Berdasarkan hasil penelitian dapat diketahui pada program pemberdayaan tampaknya BMT Amanah Ummah Sukoharjo menetapkan skala prioritas yang lebih besar pada bantuan ekonomi produktif dalam bentuk pemodalan dan pembinaan usaha. Program pemberdayaan seperti ini memang besar manfaatnya karena dengan program semacam ini akan bisa mentransfer mustahiq menjadi muzakki. Namun, sayangnya tidak seluruh program pemberdayaan ekonomi produktif ini berhasil. Tidak sedikit yang gagal karena proyek-proyek bantuan tersebut dilaksanakan tanpa dukungan data dan informasi akurat, serta tanpa dukungan kemampuan pengelolaan dan ketersediaan dana yang memadai.

Hal ini bisa dilihat dengan berkurangnya anggota Mina Baru. Ada juga program nata de coco kelompok ibu-ibu pengajian yang terpaksa bubar karena masalah lokasi. Untuk itu butuh perencanaan, pengorganisasian, pelaksanaan serta pembinaan secara matang. Perlu disiapkan juga langkah-langkah prefentif antisipatif terhadap hal-hal yang kemungkinan akan terjadi. Semua itu butuh sumber daya manusia (SDM) mumpuni, yang kreatif, inovatif dan teroganisir dengan baik guna tercapainnya hasil yang di harapkan. Sehingga seorang manager tidak harus melaksanakan sendiri semua kegiatan.

Konsep pemberdayaan yang telah dimplementasikan oleh BMT Amanah Ummah Suko- harjo tersebut dapat menjadi inspirasi bagi BMTBMT lain yang ada di Indonesia pada umumnya dan eks karisedanan Surakarta khususnya. Pemberdayaan masyarakat (empowerment comunity) merupakan tujuan ideal dalam penadayagunaan dana zakat, infak dan sedekah (ZIS). Hal ini sesuai dengan UU nomor 23 tahun 2011 tentang pengelolaan zakat bahwa zakat dapat didayagunakan untuk usaha produktif dalam rangka penanganan fakir miskin dan meningkatkan kualitas umat.

\section{Kesimpulan}

Lembaga keuangan syariah dalam konteks BMT (baitul mal wat tamwil) terdapat dua bidang usaha yang harus dijalankan secara bersinergi antara pengembangan lembaga dengan masyarakat sekitar. BMT Amanah Ummah telah berusaha mensinergikan kedua bidang tersebut dengan adanya pemisahan managemen antara Baitul Mal dan Baitul Tamwil. Baitul Mal BMT Amanah Ummah Sukoharjo memiliki pengelola dan pengelolaan tersendiri. Model pembiayaan untuk dhuafa pada BMT Amanah Ummah Sukoharjo adalah dengan menggunakan akad pembiayaan qardhul hasan. Dimana pendistribusiannya diwujudkan dalam bentuk pinjaman dana bergulir yang digunakan untuk membiayai atau mengembangkan usaha dhuafa.

Pendistribusian dana zakat infak dan sedekah (ZIS) pada Baitul Mal BMT Amanah Ummah Sukoharjo dialokasikan untuk programprogram pemberdayaann, kesehatan, pendidikan dan charity. Porsi yang lebih besar di alokasikan untuk program pemberdayaan, program semacam ini akan bisa mentransfer mustahiq menjadi muzakki.

\section{Ucapan Terimakasih}

Penulis mengucapkan terima kasih kepada segenap keluarga besar Institut Agama Islam Darussalam (IAID) Ciamis Jawa Barat dan semua pihak yang membantu dan memotivasi penulis dalam penyelesaian penelitian ini, serta segenap pimpinan dan karyawan BMT Amanah Ummah atas ketersediannya meluangkan waktu dan membantu terlaksananya penelitian ini. 
Terima kasih pula penulis haturkan kepada segenap reviewer Jurnal Ilmiah Ekonomi Islam yang telah melakukan review terhadap naskah jurnal yang penulis ajukan. Semoga kerja keras dan sumbangan pemikirannya dalam pengembangan ilmu pengetahuan tercatat sebagai amal kebaikan dan mendapat balasan dari Allah SWT. Amin.

\section{Daftar Pustaka}

Abdullah, B., \& Saebani, B. A. (2014). Metode Penelitian Ekonomi Islam (Muamalah). Bandung: Pustaka Setia.

Al-Mawardi, Imam. (t.t). Al-Ahkam AsSulthaniyyah fi Al-Ilaayat at Diniyaah, Beirut: Daar el-Kitab, al-Arrabi.

Antonio, Muhammad Syafi'i. (2001). Bank Syariah dari Teori ke Praktek, Jakarta: Gema Insani

Asytuti, R. (2012). Penilaian Kesehatan Keuangan Pada Kospin Jasa Syariah Pekalongan Sebagai Lembaga Keuangan Mikro Syariah. Jurnal Penelitian, 8(1).

Bakri, S. (2014). Pendekatan-pendekatan dalam Islamic Studies. DINIKA Journal of Islamic Studies, 12(1).

bisnis.com (2015). Baznas Targetkan Dana Zakat 2015 Sebesar Rp4,8 Triliun. http://industri.bisnis.com/read/20150630/12/ 448787/baznas-targetkan-dana-zakat-2015sebesar-rp48-triliun. Diakses 24 April 2016 pukul 07.50 WIB

Dahlan, Abdul Azis, et.al. (2003). Ensiklopedi Hukum Islam, cet VI, Jakarta: PT Ichtiar Baru Van Hoeve

Ilmi, Makhalul. (2002). Teori dan Praktek Lembaga Mikro Keuangan Syariah, Yogyakarta: UII Press

Mardalis. (1990). Metode Penelitian suatu pendekatan proposal, Jakarta: Bumi Aksara.

Mubasirun, M. (2013). Distribusi Zakat Dan Pemberdayaan Ekonomi Umat. INFERENSI Jurnal Penelitian Sosial Keagamaan, 7(2), 493-512.

Mufraini, Arief. (2006). Akuntansi dan Manajemen Zakat, Jakarta: Kencana
Padlullah, Cholid. (1993). Mengenal Hukum ZIS (Zakat Infaq dan Sedekah) dan pengamalannya di DKI Jakarta, Jakarta: Badan Amil Zakat dan Infaq/Sedekah DKI Jakarta

Quzwini, M. (2013) Pemberdayaan Masyarakat Melalui Lembaga Keuangan Mikro Syariah Baitul Mal wat Tamwil, KERABAT, tahun ke

$\mathrm{XI}$ https://kalsel2.kemenag.go.id/files/kalsel/file /file/HumasKUB/zvhf1384395293.pdf, diakes 01 Mei 2016

Rakhmat, Jalaluddin. (2005). Metode Penelitian Komunikasi dilengkapi contoh analisis statistik. Bandung: Remaja Rosdakarya.

Rasjid, Sulaiman. (2005). Fiqh Islam, cetakan ke 38, Bandung: Sinar Baru Algensindo

Ridwan, A. H. (2013). Manajemen Baitul mal wa Tamwil, Bandung: Pustaka Setia

Rivai, V., \& Usman, A. N. (2012). Islamic economic and finance: ekonomi keuangan Islam bukan alternatif tapi solusi. Gramedia.

Rofiah, K. (2010). Peran Lembaga Keuangan Mikro Dalam Pemberdayaan Ekonomi Masyarakat Di Kabupaten Ponorogo. Kodifikasia, 5(1), 1-22.

Rohmat. (2013). Manajemen Kepemimpinan Kewirausahaan, Yogyakarta: Cipta Media

Sabiq, Sayyid. (1987). Fiqhus Sunnah, Beirut: Darul Kitab al-Arabi, cetakan ke 8, Vol. III

Sonn, C. C., \& Quayle, A. F. (2014). Community Cultural Development for Social Change: Developing Critical Praxis. Journal for Social Action in Counseling \& Psychology, 6(1).

Sudarsono, Heri. (2003). Konsep Ekonomi Islam Suatu Pengantar, Yogyakarta: Ekonisia

Sumiyanto, Ahmad. (2008). BMT Menuju Koperasi Modern, Jakarta: Ises Publishing

Undang-undang No 23 tahun 2011 tentang Pengelolaan Zakat

Yusuf, S. D. (2014). Peran Strategis BMT dalam peningkatan ekonomi Rakyat, journal.iaingorontalo.ac.id/index.php/am/arti cle/view/164, diakses pada tanggal 5 Juni 2016 
Jurnal Ilmiah Ekonomi Islam, 4(02), 2018, 125

Zallum, Abdul Qodim. (2009). Al Amwal fi Lilmalayin.

Daulah al Khilafah, Beirut : Dar al-Ilmi 